\title{
Antimicrobial Activities of the Combined Use of Cuminum Cyminum L. Essential Oil, Nisin and Storage Temperature Against Salmonella typhimurium and Staphylococcus aureus In Vitro
}

\author{
Hamid Reza Tavakoli ${ }^{1}$; Zohreh Mashak ${ }^{2,}$; Bizhan Moradi ${ }^{3}$; Hamid Reza Sodagari ${ }^{4}$ \\ ${ }^{1}$ Health Research Center, Baqiyatallah University of Medical Sciences, Tehran, Iran \\ ${ }^{2}$ Department of Food Hygiene, Karaj Branch, Islamic Azad University, Karaj, Iran \\ ${ }^{3}$ Department of Microbiology, College of Sciences, Zanjan Branch, Islamic Azad University, Zanjan, Iran \\ ${ }^{4}$ Young Researchers and Elite Club, Karaj Branch, Islamic Azad University, Karaj, Iran \\ ${ }^{*}$ Corresponding author: Zohreh Mashak, Department of Food Hygiene, College of Veterinary Medicine, Karaj Branch, Islamic Azad University, Karaj, Iran. Tel: +98-9123612387, E-mail: \\ mashak@kiau.ac.ir
}

Received: November 5, 2014; Revised: February 5, 2015; Accepted: March 7, 2015

\begin{abstract}
Background: Foodborne diseases are considered as major health problems in different countries. Concerns over the safety of some chemical preservatives and negative consumer reactions to them have prompted interest in natural alternatives for the maintenance or extension of food shelf life. In this respect, the combination of a plant essential oil and nisin has used for controlling the growth of foodborne pathogens as natural food preservative using the mathematical model.

Objectives: The purpose of this study was to determine the effect of different concentrations of Cuminum cyminum L. essential oil $(0,15$, 30 and $45 \mu \mathrm{L} / 100 \mathrm{~mL})$ and nisin $(0,0.5$ and $1.5 \mu \mathrm{g} / \mathrm{mL})$ combination at different temperatures $\left(10,25\right.$ and $\left.35^{\circ} \mathrm{C}\right)$ on growth of Salmonella typhimurium and Staphylococcus aureus in the Brain-Heart Infusion (BHI) broth model. The concentrations of $0 \mu \mathrm{L} / 100 \mathrm{~mL}$ for essential oil and $0 \mu \mathrm{g} / \mathrm{mL}$ for nisin imply the negative control.

Materials and Methods: A multivariate variance experiment was performed. To assess the effect of essential oil, nisin and the incubation temperature on growth probability ( $\log \mathrm{P} \%)$ of S. typhimurium and S. aureus, four concentrations of $C$. cyminum L. essential oil ( $0,15,30$ and $45 \mu \mathrm{L} / 100 \mathrm{~mL})$, three concentrations of nisin $(0,0.5$ and $1.5 \mu \mathrm{g} / \mathrm{mL})$ and three storage temperatures $\left(10,25\right.$ and $\left.35^{\circ} \mathrm{C}\right)$ were considered.

Results: The growth of S. typhimurium was significantly decreased by the concentration of essential oil $\geq 30 \mu \mathrm{L} / 100 \mathrm{~mL}$ in combination with nisin $\geq 0.5 \mu \mathrm{g} / \mathrm{mL}$ at temperature $=10^{\circ} \mathrm{C}(\mathrm{P}<0.05)$. Also, in combination of the essential oil $\geq 15 \mu \mathrm{L} / 100 \mathrm{~mL}$ and nisin $\geq 0.5 \mu \mathrm{g} / \mathrm{mL}$ at temperature $\leq 25^{\circ} \mathrm{C}$, the growth of $S$. aureus was significantly reduced $(\mathrm{P}<0.05)$.

Conclusions: These results indicate that the combination of essential oil and nisin inhibits the growth of S. typhimurium and S. aureus bacteria and there is the possibility of using them as substitutes for chemical food preservatives. Moreover, the model (log P\%)in this study can be a good tool for the reduction of microbiological hazards in food industry.
\end{abstract}

Keywords: Antimicrobial Activity, Essential Oil; Nisin; Salmonella typhimurium; Staphylococcus aureus

\section{Background}

Foodborne diseases are considered as major health problems in different countries (1). Scallan et al. estimated that major known pathogens and unspecified agents transmitted by food result in an estimated 47.8 million illnesses, 127,839 hospitalizations, and 3037 death each year in the United States (2). Salmonella typhimurium and Staphylococcus aureus are known to have caused outbreaks through consumption of foods $(3,4)$. Concerns over the safety of some chemical preservatives and negative consumer reactions to them have prompted interest in natural alternatives for the maintenance or extension of food shelf life. Particular interest has focused on the potential applications of plant essential oils (5-7). In this respect, the plant essential oils and their components could use for controlling the growth of foodborne pathogens and food spoilage microorganisms as natural food preservatives $(8,9)$.
Cuminum cyminum L. (Cumin) from Apiaceae family is native to the Mediterranean region and has long been used in traditional medicine $(10,11)$ and many species of traditional medicinal plants of Iran are classified in this family, such as Coriander (Coriandrum sativum), Bilhar (Doremaaucheri), and Schlecht (Ferulago angulata boiss.). Cumin seeds have distinctive flavor and strong, warm aroma due to its essential oil content $(12,13)$. Nowadays, it is cultivated in China, India, Indonesia, Iran, North Africa, Pakistan, Sri Lanka, Syria, and Turkey. Iran has been the principal supplier of cumin in the world (14). C. cyminum L. is mainly used where highly spiced foods are preferred. It is stomachic, diuretic, carminative, stimulant, astringent, emmenagogic and antispasmodic $(10,11,15)$. The effect of C. cyminum L. essential oil has been well-known on growth inhibition of some fungi that have role in food

Copyright (C) 2015, Ahvaz Jundishapur University of Medical Sciences. This is an open-access article distributed under the terms of the Creative Commons Attribution-NonCommercial 4.0 International License (http://creativecommons.org/licenses/by-nc/4.0/) which permits copy and redistribute the material just in noncommercial usages, provided the original work is properly cited. 
spoilage and putrefaction $(16,17)$. The antimicrobial effect of C. cyminum L. essential oil on microorganisms such as Klebsiella pneumoniae, Vibrio spp., S. aureus, Bacillus cereus, Escherichia coli $\mathrm{O} 157: \mathrm{H7}$, S. enteritidis, and Listeria monocytogenes has been investigated in several studies $(12,13,18,19)$.

The essential oils, such as C. cyminum can be used as food preservatives. However, to establish the usefulness of natural antimicrobial preservatives, they must be evaluated alone and in combination with other preservative factors such as nisin; therefore, it can be determined whether there are synergistic effects $(20,21)$. Nisin is a ribosomal peptide (bacteriocin) that is produced by Lactococcuslactis subsp. Lactis that was adopted by joint FAO/WHO expert committee as an effective natural food preservative in food industry, such as dairy and meat products. Maximum limit of nisin is $12.5 \mathrm{mg} / \mathrm{kg}$ in food. Bactericidal activities of nisin occur by two mechanisms, create pore in bacterial cell wall and inhibition of peptidoglycan biosynthesis (20, 22-25).

In recent years the mathematical in vitro models to predict the growth kinetic, e.g. growth/ no growth and timeto-detection, of bacteria in defined system have been developed, so for this purpose, researches have done first in laboratory media and then in food model (26-28).

\section{Objectives}

The purpose of this study was to evaluate the effect of $C$. cyminum L. essential oil alone and in combination with nisin at different temperatures on growth of S. typhimurium and S. aureus in Brain-Heart Infusion (BHI) broth for 43 days. This model was designed according to previous studies (28-30).

\section{Materials and Methods}

\subsection{Plant Material}

C. cyminum L. (Linnean society of London Herbarium No. LIMN-HS511.1) was collected from Kerman province of Iran at flowering stage of plant in June 2013 and identified by Institute of Medicinal Plants of Tehran University, Tehran, Iran.

\subsection{Extraction of Essential Oil}

Air-dried seeds and aerial parts of the plant were subjected to steam distillation for 2 hours using a Clevengertype apparatus (Corning, Mexico). The essential oil was weighed, stored at $4^{\circ} \mathrm{C}$ in sealed ampoules and used within days $(11-13,15,18)$.

\subsection{Identification of Essential Oil Components}

The C. cyminum L. essential oil was analyzed by Gas Chromatography (GC) (Thermo Quest 2000, UK) and also analyzed by Gas Chromatography-Mass Spectrometery (GC-MS) (Thermo Quest/ Finnigan, UK) equipped with sil- ica capillary column $(30 \mathrm{~mm} \times 0.25 \mathrm{~mm}$ inner diameter; film thickness of $0.25 \mu \mathrm{m}$ ) and coated with DB-5. The MS was scanned in the electron impact mode, using ionization energy of 70e-V. The Retention Index (RI) for each of the separated materials was calculated based on the extraction time and identification of the major components of essential oil was confirmed by comparing their relative KovatsRI and mass spectra with the standard of the National Institute of Standards and Technology (NIST $05)$ mass spectral library and those have reported in the literature $(15,18,29)$.

\subsection{Nisin Preparation}

Nisin containing $2.5 \%$ active nisin was purchased from (Sigma Aldrich, UK). Nisin stock solution was prepared with $0.02 \mathrm{~mol} / \mathrm{L} 1 \mathrm{HCl}(\mathrm{pH} 1.6)$, and was filter-sterilized through a $0.22 \mu \mathrm{m}$ disposable sterile syringe filter (Merck, Germany).

\subsection{Test Organism}

Lyophilized cultures of Salmonella typhimurium ATCC 14028 and Staphylococcus aureus ATCC 25923 were obtained from department of microbiology, faculty of veterinary medicine, University of Tehran, Iran. Consequently, the lyophilized culture was grown in a tube containing $10 \mathrm{~mL}$ of BHI broth (Merck, Germany) twice and incubated at $35^{\circ} \mathrm{C}$ for 18 hours. Then cultures were stored at $20^{\circ} \mathrm{C}$ with $10 \%$ sterile glycerol in $1 \mathrm{~mL}$ microtubes and their subcultures were used as working cultures.

\subsection{Inoculums Preparation}

Salmonella typhimurium and S. aureus inoculums were prepared by transferring from working culture to the sterile BHI broth. They were grown for 18 hours at $35^{\circ} \mathrm{C}$, and then second subculture was prepared by incubation for 18 hours at $35^{\circ} \mathrm{C}$. Different values from second cultures were transferred to the $13 \times 100 \mathrm{~mm}$ cuvettes containing $5 \mathrm{~mL}$ sterile BHI broth and they were adjusted to Optical Density (OD) (absorbance) of 0.02 and 0.01 at $600 \mathrm{~nm}$ for S. typhimurium and S. aureus cultures respectively, using a spectronic 20 spectrophotometer (Boeckel and Co., Germany). Thus, bacterial suspensions were adjusted with the same concentration to contain approximately $1 \times 10^{7}$ $\mathrm{CFU} / \mathrm{mL}$. The bacterial suspensions were enumerated by performing 10 -fold serial dilutions and surface plating culture on BHI agar. Then colony counting was done after a 24-hour incubation period at $35^{\circ} \mathrm{C}(28)$.

\subsection{Preparation of Broth Substrate}

The BHI broth with 5\% (v/v) di-methylsulfoxid (DMSO, Merck Schuchardt OHG, Hohenbrunn, Germany) and $0.05 \%(w / v)$ agar (Merck, Germany) was prepared as a stabilizer in three $4000 \mathrm{~mL}$ screw-capped glass bottles (Sigma-Aldrich Co., USA) and then autoclaved at $121^{\circ} \mathrm{C}$ for 15 minutes (31). 
Tavakoli HR et al.

\subsection{Preparation of In Vitro Model}

A multivariate variance experiment was performed. To assess the effect of essential oil, nisin and incubation temperature on growth probability $(\log \mathrm{P} \%)$ of S. typhimurium and S. aureus, four concentrations of C. cyminum L. essential oil $(0,15,30$ and $45 \mu \mathrm{L} / 100 \mathrm{~mL})$, three concentrations of nisin $(0,0.5$ and $1.5 \mu \mathrm{g} / \mathrm{mL})$ and three storage temperatures $\left(10,25\right.$ and $\left.35^{\circ} \mathrm{C}\right)$ were considered. Thus, 36 different levels $(4 \times 3 \times 3)$ were used for each microorganism. For each combination of essential oil-nisin-temperatures, 8 bacterial dilution of $10^{5}$ to $10^{-2} \mathrm{CFU} / \mathrm{mL}$ from S. typhimurium and S. aureus in the $16 \times 100 \mathrm{~mm}$ screw-capped tubes contained $9 \mathrm{~mL}$ BHI broth were obtained and stored for up to 43 days. Time to visible turbidity at 18 intervals (1, 2, $3,4,5,6,7,8,13,16,19,22,25,28,31,34,37$ and 43 days) was recorded. All of the experimental processes were done for triplet repeat.

\subsection{Calculation of Probability of Growth ( $\log P \%)$}

The Log P\% was calculated from total tubes (out of 36) for each essential oil-nisin-temperature combination showing visible growth up to a certain observation time, using $3 \times 8$ Most Probable Number (MPN) method (27). The fraction of the inoculum which was inhibited by each broth environment up to that time was estimated from the formula $\log _{10} \mathrm{I} / \mathrm{G}$, where I was the number of cells inoculated in the highest cell concentration tube and G was the MPN of cells in the same tube, which managed to grow. The probability percentage $(\mathrm{P} \%)$ of any given cell initiating growth under each broth environment within a certain period of time was defined as $\mathrm{P} \%=100 / \operatorname{antilog}\left(\log _{10} \mathrm{I} / \mathrm{G}\right)$. The number of cells needed to initiate visible growth for each essential oil-nisin-temperature combination was estimated from cells needed $=100 / \mathrm{P} \%(28)$.

\subsection{Statistical Analysis}

The main and interactive effects of independent variables of temperature, concentration of nisin, essential oil and storage time (day) on dependent variables of log P\% of S. typhimurium and S. aureus were evaluated by analysis of variance (ANOVA) using IBM SPSS Statistics software version 22 (27).

\section{Results}

\subsection{Chemical Compositions of Cuminum cyminum L.Essential Oil}

In this study, the yield of the essential oil of air-dried seeds and aerial parts of plant samples of C.cyminum L. was 3.56\% $(\mathrm{v} / \mathrm{w})$. The results for the percentages of the components of essential oil (as determined by GC/MS) are shown in Table 1. From the C. cyminum L. essential oil, 16 components were identified, representing 91.96\% (area percent) of the total essential oil, which $\delta$-Terpinene $(22.30 \%)$ and Cuminaldehyde $(21.09 \%)$ were the major components. Other important components were $<$ ortho $>$ Cymene (12.71\%), $\beta$-Pinene (8.46\%) and < para > Cymene-7-ol (6.67\%) (Table 1).

Table 1. Main Components and the Relative Contents of Cuminum cyminum L. Essential Oil

\begin{tabular}{|c|c|c|c|c|c|}
\hline \multirow[b]{2}{*}{ Retention Index } & \multicolumn{4}{|c|}{ Components } & \multirow[b]{2}{*}{ Percent } \\
\hline & Monoterpenes Hydrocarbons & $\begin{array}{l}\text { Oxygenated Monoter- } \\
\text { penes }\end{array}$ & $\begin{array}{l}\text { Sesquiterpene } \\
\text { Hydrocarbons }\end{array}$ & Others & \\
\hline 11.27 & $\alpha$-Pinene & & & & 1.26 \\
\hline 13.55 & $\beta$-Pinene & & & & 8.46 \\
\hline 14.21 & Myrcene & & & & 0.88 \\
\hline 14.83 & Phellandrene & & & & 1.59 \\
\hline 16.11 & $<$ ortho $>$ Cymene & & & & 12.71 \\
\hline 16.29 & Limonene & & & & 4.63 \\
\hline 16.66 & $\beta$-Ocimene $<Z>$ & & & & 1.17 \\
\hline 18.09 & $\delta$-Terpinene & & & & 22.30 \\
\hline 19.18 & $\alpha$-Terpinolene & & & & 0.94 \\
\hline 27.03 & & Cumin aldehyde & & & 21.09 \\
\hline 28.83 & & Menth-1-en-7-al < para > & & & 5.99 \\
\hline 29.16 & & $<$ para $>$ Cymen-7-ol & & & 6.67 \\
\hline 34.60 & & & Caryophyllene & & 0.87 \\
\hline 36.91 & & & $\beta$-Acoradien & & 1.27 \\
\hline 38.74 & & & & Myristicin & 1.20 \\
\hline 42.72 & & & & Dill apiole & 0.93 \\
\hline Total identified & 53.94 & 33.75 & 2.14 & 2.13 & 91.96 \\
\hline
\end{tabular}


Tavakoli HR et al.

\subsection{Factor Effects}

In the present study, the log $\mathrm{P} \%$ was used in a factorial design study to quantify the effects of essential oil-nisintemperature and day (for $\log \mathrm{P} \%$ ) on the bacterial growth responses in BHI broth $(28,29)$. Table 2 represents the values of $\log \mathrm{P} \%$ at day to reach the maximum probability of growth for S. typhimurium and S. aureus and cells needed as affected by combinations of essential oil, nisin, and temperature in BHI broth model.

The essential oil without nisin (nisin $=0.0 \mu \mathrm{g} / \mathrm{mL}$ ), at all temperature (Temperature $\leq 35^{\circ} \mathrm{C}$ ) could not obviously affect the growth of the S. typhimurium in this study. Whereas, essential oil $\geq 45 \mu \mathrm{L} / 100 \mathrm{~mL}$ without nisin, at all temperature (Temperature $\leq 35^{\circ} \mathrm{C}$ ) have a significant inhibitory action on S. aureus in this study $(\log \mathrm{P} \%=-3.52$ to 2.97 and cells needed $=0.11$ to $3.33 \times 10^{5}$ ).

The nisin $\geq 1.5 \mu \mathrm{g} / \mathrm{mL}$ without essential oil (essential oil $=0 \mu \mathrm{L} / 100 \mathrm{~mL}$ ) and temperature $\leq 25^{\circ} \mathrm{C}$ showed an inhibitory effect on S. typhimurium. However, the inhibitory effect of nisin on S. aureus was stronger and could affect growth of it at nisin $\geq 1.5 \mu \mathrm{g} / \mathrm{mL}$ without essential oil (essential oil $=0 \mu \mathrm{L} / 100 \mathrm{~mL}$ ) at all temperature (temperature $\leq 35^{\circ} \mathrm{C}$ ). Moreover, the inhibitory effects of essential oil and nisin were enhanced by decreasing the storage temperature to $10^{\circ} \mathrm{C}(\mathrm{P} \leq 0.05)$.

The combination of essential oil and nisin strongly affected the growth of S. typhimurium and S. aureus at the different temperatures. By applying essential oil $\geq 30$ $\mu \mathrm{L} / 100 \mathrm{~mL}$ and nisin $\geq 0.5 \mu \mathrm{g} / \mathrm{mL}$ at temperature $=10^{\circ} \mathrm{C}$, a significant decrease of $\log \mathrm{P} \%$ was observed for S. typhimurium $(\log \%=1.38$ to 3.66 and cells needed $=0.02$ to 4.17) $(\mathrm{P} \leq 0.05)$. Also, the growth of $S$. aureus in the same conditions was completely inhibited $(\log \mathrm{P} \%=-3.52$ and cells needed $=3.33 \times 10^{5}$ ).

At temperature $\geq 25^{\circ} \mathrm{C}$, the combination of essential oil and nisin (essential oil $\geq 15 \mu \mathrm{L} / 100 \mathrm{~mL}$, nisin $\geq 0.5 \mu \mathrm{g} / \mathrm{mL}$ and temperature $\leq 25^{\circ} \mathrm{C}$ ) could reduce the growth of $S$. aureus $(\log \mathrm{P} \%=1.38$ to 1.63 and cells needed $=2.33$ to 4.17 ).

According to the results of ANOVA (P values), the logP\% of S. typhimurium and S. aureus was affected significantly $(P<0.01)$ by essential oil, nisin, temperature, day, twoway interactions of essential oil $\times$ temperature, nisin $\times$ temperature, and essential oil $\times$ nisin and three-way interactions of essential oil $\times$ nisin $\times$ temperature.

\section{Discussion}

Articles of medicinal plant have been reported a better antibacterial effect of essential oil in comparison with alcoholic extract, hydro-extract and powder of plant. This antibacterial effect of essential oils is related to main components of them (8). These components, with a chemical structure including an aromatic ring, are able to disintegrate the outer membrane of bacteria and increase the permeability of the cytoplasmic membrane to the ATP (32). The main component of C. cyminum L. essential oil is cuminaldehyde or 4-isopropylbenzaldehyde and other principle active components are alpha and beta pinene, alcohol of cumin, di-pentene, para-cymene, and betaphellandrene $(18,33,34)$. These components, which have the foresaid structure are chiefly responsible for the antibacterial properties of essential oils (8). The profile of the C. cyminum L. essential oil was also in agreement with values reported from other studies. Nanasombat and Lohasupthawee concluded that the major components of this essential oil arecuminaldehyde (20.72\%) and monoterpene hydrocarbons (e.g. $\beta$-pinene, $\gamma$-terpinene, $p$-cymene) (34). Derakhshan reported components of essential oil including cuminaldehyde (25.2\%), $\rho$-mentha-1,3-dien-7al (13\%), $\rho$-mentha-1,4-dien-7-al (16.6\%), $\delta$-terpinene (19\%), $\rho$-cymene (7.2\%) and $\beta$-pinene (10.4\%).Other components were $\alpha$-thujene $(0.2 \%), \alpha$-pinene $(0.6 \%)$, sabinene $(0.7 \%)$, myrcene $(0.8 \%), \alpha$-phellandrene $(0.4 \%), \beta$-phellandrene (0.7\%) and $\rho$-menth-3-en-7-al (5.1\%) (18). Similar findings have been reported by Gachkar et al. as a result of GC-MS analyses, C. cyminum contained $\alpha$-pinene (29.2\%), 1, 8-cineole (17.9\%), and linalool (10.4\%) (12).

The different qualitative and quantitative chemicalcompositions of these essential oils with respect to previous investigations could be related firstly and foremost to the different environmental conditions, genetics (degree of hybridization), geographical origin and a harvest period $(35,36)$.

Plant essential oils are potentially useful sources of antimicrobial components (5-9). However, findings reported from studies of essential oils antimicrobial effects are difficult to compare, because the test methods, bacterial strains and source of antimicrobial agents are different $(29,37,38)$.

In many researches, the antimicrobial activity of $C$. cyminum L. on different bacteria such as P. aeroginosa, Vibrio spp., K. pnomonia and others have surveyed and concluded that $C$. cyminum L. along with the effect of broadspectrum antibiotics inhibit the growth of pathogenic bacteria $(13,18,39)$

Gachkar et al. surveyed kinetics of death of E. coli, S. aureus and L. monocytogenes exposed to the Minimum Bactericidal Concentration levels of C. cyminum L. and Rosmarinus officinalis essential oils that $C$. cyminum $\mathrm{L}$. essential oil exhibited stronger antimicrobial activity than $\operatorname{did} R$. officinalis essential oil. They suggested that C. cyminum $\mathrm{L}$. essential oil may be considered as potent agents in food preservation (12).

Chaudhry and Tariq investigated the antibacterial activity of different essential oils such as aqueous Nigella sativa L., C. cyminum L., and Papaver somniferum L. against 188 bacterial isolates and the highest antibacterial potential was observed for C. cyminum L. (33). Derakhshan et al. also found that growth of $K$. pneumonia strains exposed to sub-MICs of C.cyminum L. extracts resulted in cell elongation and repression of capsule expression (18). Hajlaoui et al. reported the high effectiveness of $C$. cyminum L. essential oil against Vibrio spp. Strains and their antibacterial, antifungal and antioxidant components can be used for therapeutic or nutraceutical industries (13). 
Tavakoli HR et al.

Table 2. $\log _{10}$ Probability Percentage of Growth Initiation at the Day to Reach the Maximum Probability of Growth for S. typhimurium and S. aureus, the Number of cells needed to Initiate Growth During 43 Days of Storage in BHI Broth, as Affected by Combinations of Cuminum cyminum L. Essential oil, Nisin, and Temperature

\begin{tabular}{|c|c|c|c|c|c|c|c|c|}
\hline \multirow{2}{*}{$\begin{array}{l}\text { Temper- } \\
\text { ature, }{ }^{\circ} \mathrm{C}\end{array}$} & \multirow{2}{*}{$\begin{array}{c}\text { Essential oil, } \\
\mu \mathrm{L} / \mathbf{1 0 0} \mathrm{mL}\end{array}$} & \multirow{2}{*}{$\begin{array}{l}\text { Nisin, } \\
\mu \mathrm{g} / \mathrm{mL}\end{array}$} & \multicolumn{3}{|c|}{ S.typhimurium } & \multicolumn{3}{|c|}{ S. aureus } \\
\hline & & & Day & $\begin{array}{l}\text { Growth Initia- } \\
\text { tion, } \%\end{array}$ & $\begin{array}{l}\text { Cells } \\
\text { Need }\end{array}$ & Day & $\begin{array}{l}\text { Growth Initia- } \\
\text { tion, } \%\end{array}$ & Cells Need \\
\hline 10 & 0 & 0.0 & 12 & 3.66 & 0.02 & 16 & -1.34 & $2.17 \times 103$ \\
\hline 10 & 0 & 0.5 & 25 & 3.66 & 0.02 & 16 & -1.34 & $2.17 \times 103$ \\
\hline 10 & 0 & 1.5 & 25 & 2.97 & 0.11 & $>43$ & -3.44 & $2.78 \times 105$ \\
\hline 10 & 15 & 0.0 & 25 & 3.66 & 0.02 & 16 & -1.34 & $2.17 \times 103$ \\
\hline 10 & 15 & 0.5 & 31 & 3.66 & 0.02 & 16 & -2.64 & $4.35 \times 104$ \\
\hline 10 & 15 & 1.5 & 31 & 2.97 & 0.11 & $>43$ & -3.52 & $3.33 \times 105$ \\
\hline 10 & 30 & 0.0 & 25 & 3.66 & 0.02 & 16 & -1.34 & $2.17 \times 103$ \\
\hline 10 & 30 & 0.5 & 31 & 3.38 & 0.04 & $>43$ & -3.52 & $3.33 \times 105$ \\
\hline 10 & 30 & 1.5 & 31 & 1.38 & 4.17 & $>43$ & -3.52 & $3.33 \times 105$ \\
\hline 10 & 45 & 0.0 & 28 & 3.66 & 0.02 & $>43$ & -3.52 & $3.33 \times 105$ \\
\hline 10 & 45 & 0.5 & 31 & 2.97 & 0.11 & $>43$ & -3.52 & $3.33 \times 105$ \\
\hline 10 & 45 & 1.5 & 37 & 1.38 & 4.17 & $>43$ & -3.52 & $3.33 \times 105$ \\
\hline 25 & 0 & 0.0 & 1 & 3.66 & 0.02 & 2 & 3.38 & 0.04 \\
\hline 25 & 0 & 0.5 & 1 & 3.66 & 0.02 & 2 & 3.38 & 0.04 \\
\hline 25 & 0 & 1.5 & 3 & 3.18 & 0.07 & 3 & 1.63 & 2.33 \\
\hline 25 & 15 & 0.0 & 1 & 3.66 & 0.02 & 2 & 3.38 & 0.04 \\
\hline 25 & 15 & 0.5 & 2 & 3.66 & 0.02 & 3 & 1.63 & 2.33 \\
\hline 25 & 15 & 1.5 & 3 & 2.88 & 0.13 & 4 & 1.38 & 4.17 \\
\hline 25 & 30 & 0.0 & 1 & 3.66 & 0.02 & 2 & 3.38 & 0.11 \\
\hline 25 & 30 & 0.5 & 2 & 3.66 & 0.02 & 3 & 1.38 & 4.17 \\
\hline 25 & 30 & 1.5 & 3 & 2.30 & 0.50 & 3 & 1.38 & 4.17 \\
\hline 25 & 45 & 0.0 & 1 & 3.66 & 0.02 & 3 & 2.97 & 0.11 \\
\hline 25 & 45 & 0.5 & 2 & 3.66 & 0.02 & 4 & 1.38 & 4.17 \\
\hline 25 & 45 & 1.5 & 4 & 2.18 & 0.67 & 4 & 1.38 & 4.17 \\
\hline 35 & 0 & 0.0 & 1 & 3.66 & 0.02 & 2 & 4.04 & 0.01 \\
\hline 35 & 0 & 0.5 & 1 & 3.66 & 0.02 & 2 & 4.04 & 0.01 \\
\hline 35 & 0 & 1.5 & 2 & 3.66 & 0.02 & 3 & 1.63 & 2.33 \\
\hline 35 & 15 & 0.0 & 1 & 3.66 & 0.02 & 2 & 4.04 & 0.01 \\
\hline 35 & 15 & 0.5 & 2 & 3.66 & 0.02 & 2 & 1.63 & 2.33 \\
\hline 35 & 15 & 1.5 & 2 & 2.97 & 0.11 & 3 & 1.38 & 4.17 \\
\hline 35 & 30 & 0.0 & 1 & 3.66 & 0.02 & 2 & 4.04 & 0.01 \\
\hline 35 & 30 & 0.5 & 2 & 3.66 & 0.02 & 3 & 1.38 & 4.17 \\
\hline 35 & 30 & 1.5 & 2 & 2.97 & 0.11 & 3 & 1.38 & 4.17 \\
\hline 35 & 45 & 0.0 & 1 & 3.66 & 0.02 & 3 & 2.97 & 0.11 \\
\hline 35 & 45 & 0.5 & 2 & 3.66 & 0.02 & 3 & 1.38 & 4.17 \\
\hline 35 & 45 & 1.5 & 2 & 2.38 & 0.42 & 3 & 1.38 & 4.17 \\
\hline
\end{tabular}

Leistner and Goris already suggested that food preservation by multiple preservatives in small amounts was superior to preservation by a large amount of a single preservative in order to both secure microbial stability and safety (40).

Natural products and derived components from plants 
Tavakoli HR et al.

may have applications in controlling pathogens in food. However, to establish the usefulness of natural antimicrobials, they must be evaluated alone or in combination with other hurdles. Moreover, Valero and Salmeron determined the synergistic effects in order to both secure microbial stability and safety and maintain the sensory, nutritive and economic properties of the foods (38).

Our results (Table 2 ) showed a significant inhibitory effect of essential oil in combination with nisin on S. typhimurium and S. aureus growth in the BHI broth which is similar to the findings of Valero and Giner that showed the synergistic effect of essential oils with nisin in food model system on bacterial growth (41).

The effect of combining nisin and essential oils has studied. Nevertheless, Rajkovic et al. observed the accomplished growth inhibition of B. cereus and Bacillus circulans strains affected by antimicrobial potential of combination of supplemented nisin and carvacrol essential oil in the BHI broth model and vacuum-packed potato puree (42). Moosavy et al. reported that the combination of Zataria multiflora Boiss. essential oil and nisin at low concentrations exhibited a higher activity against S. typhimuriumand S. aureus than individual essential oils applied at higher concentrations (43). Pajohi et al. investigated effects of the C. cyminum L. essential oil alone and in combination with nisin on survival of vegetative forms of B. cereus and B. Subtilis in a food model (commercial barley soup) that a synergistic effect of the essential oil in combination with the lowest concentration of nisin at $8^{\circ} \mathrm{C}$ was observed on the bacterial growth (44).

Misaghi and Akhondzadeh Basti showed that the growth of the B. cereus ATCC 11778 was completely inhibited at combinations Z. multiflora Boiss. essential oil $\geq$ $0.015 \%$, nisin $\geq 1.5 \mu \mathrm{g} / \mathrm{mL}$, temperature $\leq 30^{\circ} \mathrm{C}$ and $\mathrm{pH} \leq$ 7.4 during 43 days of storage (30). They recommended to apply essential oils as a part of a hurdle system and to use them as antimicrobial components with other preservation techniques e.g. in combination with reduced temperature or other natural preservatives such as nisin.

Since essential oil containing mainly phenolic compounds and nisin acts on bacterial cytoplasmic membrane, their antibacterial activity could be enhanced by treatments involving combination of them (45). Therefore, synergism between essential oils and other parameters in antimicrobial action must be considered and further research is needed to evaluate the effectiveness of combined essential oils in the current and other food systems as well as by using active packaging, in order to assess their performance as natural antimicrobial agents in food preservation and safety (46).

Our results in this study indicate the good potential antimicrobial effect of C. cyminum L. essential oil and nisin combination on S. typhymurium growth at $10^{\circ} \mathrm{C}$ and S. aureus growth at $10^{\circ} \mathrm{C}$ and $25^{\circ} \mathrm{C}$ in the $\mathrm{BHI}$ broth during 43 days. Such models offer a cost-effective approach to control the microbial growth response in foods.

\section{Authors' Contributions}

Study concept and design: Hamid Reza Tavakoli, Zohreh Mashak, and Bizhan Moradi. Analysis and interpretation of data:Hamid Reza Tavakoli, Zohreh Mashak, and Bizhan Moradi. Drafting of the manuscript: Bizhan Moradi and Hamid Reza Sodagari. Critical revision of the manuscript for important intellectual content: Zohreh Mashak, Hamid Reza Tavakoli, Bizhan Moradi and Hamid Reza Sodagari. Statistical analysis: Bizhan Moradi.

\section{Funding/Support}

This study was supported by the institute of lifestyle research of Baqiatollah University of Medical Sciences, Tehran, Iran and administered by department of food hygiene-college of veterinary medicine, Islamic Azad University, Karaj Branch, Karaj, Iran.

\section{References}

1. Painter JA, Hoekstra RM, Ayers T, Tauxe RV, Braden CR, Angulo F et al. Attribution of foodborne illnesses, hospitalizations, and deaths to food commodities by using outbreak data, United States, 1998-2008. Emerg Infect Dis. 2013;19(3):407-15.

2. Scallan E, Kirk M, Griffin PM. Estimates of Disease Burden Associated with Contaminated Food in the United States and Globally. In: Morris GJ, Potter M editors. Foodborne Infections and Intoxications. 4 ed. San Diego, USA: Elsevier; 2013. pp. 3-18.

3. Centers for Disease Control and Prevention . Foodborne disease outbreaks. 1998. Available from: http://www.cdc.gov/foodborneoutbreaks..

4. Centers for Disease Control and Prevention.. Foodborne disease outbreaks. 2006. Available from: http://www.cdc.gov/foodborneoutbreaks..

5. Smith-Palmer A, Stewart J, Fyfe L. The potential application of plant essential oils as natural food preservatives in soft cheese. Food Microbiol. 2001;18(4):463-70.

6. Tajkarimi MM, Ibrahim SA, Cliver DO. Antimicrobial herb and spice compounds in food. Food Control.2010;21(9):1199-218.

7. Tassou C, Koutsoumanis K, Nychas GJE. Inhibition of Salmonella enteritidis and Staphylococcus aureus in nutrient broth by mint essential oil. Food Res Int. 2000;33(3-4):273-80

8. Burt S. Essential oils: their antibacterial properties and potential applications in foods--a review. Int J Food Microbiol. 2004;94(3):223-53.

9. Holley RA, Patel D. Improvement in shelf-life and safety of perishable foods by plant essential oils and smoke antimicrobials. Food Microbiol. 2005;22(4):273-92.

10. Milan KSM, Dholakia H, Tiku P, Vishveshwaraiah P. Enhancement of digestive enzymatic activity by cumin (Cuminum cyminum L.) and role of spent cumin as a bionutrient. Food Chem. 2008;110(3):678-83.

11. Sahana K, Nagarajan S, Rao LJM. Chemistry and Role in Health and Disease Prevention, Nuts Seeds in Health \& Disease Prevention. 2011. p. 417-27.Cumin (Cuminum cyminum L.) Seed Volatile Oil.

12. Gachkar L, Yadegari D, Rezaei M, Taghizadeh M, Astaneh S, Rasooli I. Chemical and biological characteristics of Cuminum cyminum and Rosmarinus officinalis essential oils. Food Chem. 2007;102(3):898-904.

13. Hajlaoui H, Mighri H, Noumi E, Snoussi M, Trabelsi N, Ksouri R, et al. Chemical composition and biological activities of Tunisian Cuminum cyminum L. essential oil: a high effectiveness against Vibrio spp. strains. Food Chem Toxicol. 2010;48(8-9):2186-92.

14. Skrovankova S, Misurcova L, Machu L. Antioxidant activity and protecting health effects of common medicinal plants. Adv Food Nutr Res. 2012;67:75-139.

15. Jalali-Heravi M, Zekavat B, Sereshti H. Use of gas chromatogra- 
phy-mass spectrometry combined with resolution methods to characterize the essential oil components of Iranian cumin and caraway. J Chromatogr A. 2007;1143(1-2):215-26.

16. Akgul A, Kivanc M. Inhibitory effects of selected Turkish spices and oregano components on some foodborne fungi. Int J Food Microbiol. 1988;6(3):263-8.

17. Naeini A, Khosravi AR, Chitsaz M, Shokri H, Kamlnejad M. AntiCandida albicans activity of some Iranian plants used in traditional medicine. J Med Mycol. 2009;19(3):168-72.

18. Derakhshan S, Sattari M, Bigdeli M. Effect of subinhibitory concentrations of cumin (Cuminum cyminum L.) seed essential oil and alcoholic extract on the morphology, capsule expression and urease activity of Klebsiella pneumoniae. Int J Antimicrob Agents. 2008;32(5):432-6.

19. Oroojalian F, Kasra-Kermanshahi R, Azizi M, Bassami MR. Phytochemical composition of the essential oils from three Apiaceae species and their antibacterial effects on food-borne pathogens. Food Chem. 2010;120(3):765-70.

20. Pol IE, Krommer J, Smid EJ. Bioenergetic consequences of nisin combined with carvacrol towards Bacillus cereus. Int Food Sci Emerg Tech. 2002;3:55-61.

21. Pol IE, Smid EJ. Combined action of nisin and carvacrol on Bacillus cereus and Listeria monocytogenes. Lett Appl Microbiol. 1999;29(3):166-70.

22. Chi-Zhang Y, Yam KL, Chikindas ML. Effective control of Listeria monocytogenes by combination of nisin formulated and slowly released into a broth system. Int J Food Microbiol. 2004;90(1):15-22.

23. Ettayebi K, El Yamani J, Rossi-Hassani B. Synergistic effects of nisin and thymol on antimicrobial activities in Listeria monocytogenes and Bacillus subtilis. FEMS Microbiol Lett. 2000;183(1):191-5.

24. Periago PM, Moezelaar R. Combined effect of nisin and carvacrol at different $\mathrm{pH}$ and temperature levels on the viability of different strains of Bacillus cereus. Int J Food Microbiol. 2001;68(1-2):141-8.

25. Jay MJ. Modern Food Microbiology. 7 ed:An Aspen Publication; 2005.

26. Wang SY, Chen PF, Chang ST. Antifungal activities of essential oils and their constituents from indigenous cinnamon (Cinnamomum osmophloeum) leaves against wood decay fungi. Bioresour Technol. 2005;96(7):813-8.

27. Fisher RA, Yates F. Statistical Tables for Biological Agricultural and Medical Research. 5 edLondon: Oliver and Boyd,; 1957.

28. RazavilarV, Genigeorgis C. Prediction of Listeria spp. growth as affected by various levels of chemicals, $\mathrm{pH}$, temperature and storage time in a model broth. Int J Food Microbiol. 1998;40(3):149-57.

29. Raoufy MR, Gharibzadeh S, Abbasifar R, Radmehr B, Akhondzadeh Basti A, Abbasifar A, et al. Modeling the growth of Salmonella typhimurium under the effect of Zataria multiflora essential oil, $\mathrm{pH}$, and temperature by artificial neural networks. Compar Clin Pathol. 2011;20(5):507-12.

30. Misaghi A, Akhondzadeh Basti A. Effects of Zataria multiflora Boiss. essential oil and nisin on Bacillus cereus ATCC 11778. Food Control. 2007;18(9):1043-9.

31. Mann CM, Markham JL. A new method for determining the mini- mum inhibitory concentration of essential oils. J Appl Microbiol. 1998;84(4):538-44.

32. Helander IM, Alakomi H-L, Latva-Kala K, Mattila-Sandholm T, Po I, Smid EJ, et al. Characterization of the Action of Selected Essential Oil Components on Gram-Negative Bacteria. J Agri Food Chem. 1998;46(9):3590-5.

33. Chaudhry NMA, Tariq P. In vitro antibacterial activities of kalonji, cumin and poppy seed. PakJ Bot. 2008;40(1):461-7.

34. Nanasombat S, Lohasupthawee P. Antibacterial activity of ethanolic extracts and essential oils of spices against Salmonella and other Enterobacteria. KMITL Sci Tech J . 2005;5(3):527-38.

35. Slavkovska V, Jancic R, Bojovic S, Milosavljevic S, Djokovic D. Variability of essential oils of Satureja montana L. and Satureja kitaibelii wierzb. ex Heuff. from the central part of the balkan peninsula. Phytochemistry. 2001;57(1):71-6.

36. Mastelić J, Jerković I. Gas chromatography-mass spectrometry analysis of free and glycoconjugated aroma compounds of seasonally collected Satureja montana L. Food Chem. 2003;80(1):135-40.

37. Bagamboula CF, Uyttendaele M, Debevere J. Inhibitory effect of thyme and basil essential oils, carvacrol, thymol, estragol, linalool and p-cymene towards Shigella sonnei and S. flexneri. Food Microbiol. 2004;21(1):33-42.

38. Valero M, Salmeron MC. Antibacterial activity of 11 essential oils against Bacillus cereus in tyndallized carrot broth. Int J Food Microbiol. 2003;85(1-2):73-81.

39. Hosseini Jazani N, Zartoshti M, Shahabi S. Antibacterial Effects of Iranian Cuminum cyminum Essential Oil on Burn Isolates of Pseudomonas aeruginosa. Int J Pharmacol. 2008;4(2):157-9.

40. Leistner L, Gorris LGM. Food preservation by hurdle technology. Trends Food Sci Technol. 1995;6(2):41-6.

41. Valero M, Giner MJ. Effects of antimicrobial components of essential oils on growth of Bacillus cereus INRA L2104 in and the sensory qualities of carrot broth. Int J Food Microbiol. 2006;106(1):90-4.

42. Rajkovic A, Uyttendaele M, Courtens T, Debevere J. Antimicrobial effect of nisin and carvacrol and competition between Bacillus cereus and Bacillus circulans in vacuum-packed potato puree. Food Microbiol. 2005;22(2-3):189-97.

43. Moosavy M-H, Akhondzadeh Basti A, Misaghi A, Zahraei Salehi T, Abbasifar R, Mousavi Ebrahimzadeh HA, et al. Effect of Zataria multiflora Boiss. essential oil and nisin on Salmonella typhimurium and Staphylococcus aureus in a food model system and on the bacterial cell membranes. Food Res Int. 2008;41(10):1050-7.

44. Pajohi MR, Tajik H, Farshid AA, Hadian M. Synergistic antibacterial activity of the essential oil of Cuminum cyminum L. seed and nisin in a food model. J Appl Microbiol. 2011;110(4):943-51.

45. Yamazaki K, Yamamoto T, Kawai Y, Inoue N. Enhancement of antilisterial activity of essential oil constituents by nisin and diglycerol fatty acid ester. Food Microbiol. 2004;21(3):283-9.

46. Camo J, Beltran JA, Roncales P. Extension of the display life of lamb with an antioxidant active packaging. Meat Sci. 2008;80(4):1086-91. 